\title{
André Gide, La Symphonie pastorale
}

\section{Gian Luigi Di Bernardini}

\section{(2) OpenEdition}

\section{Journals}

\section{Édition électronique}

URL : http://journals.openedition.org/studifrancesi/8055

DOI : ERREUR PDO dans /localdata/www-bin/Core/Core/Db/Db.class.php L.34 : SQLSTATE[HYO00]

[2006] MySQL server has gone away

ISSN : 2421-5856

\section{Éditeur}

Rosenberg \& Sellier

\section{Édition imprimée}

Date de publication : 1 juillet 2009

Pagination : 435

ISSN : 0039-2944

\section{Référence électronique}

Gian Luigi Di Bernardini, «André Gide, La Symphonie pastorale », Studi Francesi [En ligne], 158 (LIII | II) | 2009, mis en ligne le 30 novembre 2015, consulté le 07 janvier 2021. URL : http://

journals.openedition.org/studifrancesi/8055 ; DOI : https://doi.org/ERREUR PDO dans /localdata/ www-bin/Core/Core/Db/Db.class.php L.34 : SQLSTATE[HY000] [2006] MySQL server has gone away

Ce document a été généré automatiquement le 7 janvier 2021.

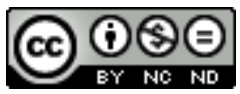

Studi Francesi è distribuita con Licenza Creative Commons Attribuzione - Non commerciale - Non opere derivate 4.0 Internazionale. 


\title{
André Gide, La Symphonie pastorale
}

\author{
Gian Luigi Di Bernardini
}

\section{RÉFÉRENCE}

ANDRÉ GIDE, La Symphonie pastorale, Dossier par Lucien GIRAUDO, Lecture d'image par Ferrante Ferranti, Paris, Gallimard, 2008 («Folioplus»), pp. 178.

1 Les éditions Gallimard rééditent La Symphonie pastorale, l'un des romans les plus élégants d'André Gide. Le Dossier (pp. 99-178), dirigé par Lucien Giraudo, se compose de deux parties. La première, De la photographie au texte (pp. 99-113), présente les considérations de Ferrante Ferranti sur de possibles liens entre l'Ophélie de Julie Margaret Cameron (profil en noir et blanc d'une jeune fille pris en 1867 et reproduit sur la couverture) et Gertrude, la jeune aveugle co-protagoniste du roman.

2 L'allusion shakespearienne du titre de la photo s'explique assez aisément: Julie Cameron est une photographe cultivée, elle a illustré les œuvres poétiques de Milton et de Tennyson et son travail est influencé par l'esthétisme religieux des préraphaélites.

3 Ferranti justifie son rapprochement en s'appuyant sur la traduction gidienne d'Hamlet et en établissant un parallèle entre «la scène de folie au cours de laquelle Ophélie décrit les fleurs, et la prière incarnée de sa tirade finale» et «l'énumération enjouée de la promenade de Gertrude et l'exaltation de son agonie» (p. 113).

4 La deuxième partie du Dossier, Le texte en perspective (pp. 115-178), s'appuie sur des éléments habituels: la biographie de l'auteur, les éléments structurels du texte, les références intertextuelles, les influences précédentes parmi lesquelles il faut souligner le Symbolisme, au milieu duquel Gide a créé ses premiers ouvrages. Le volume se termine sur des suggestions, adressées à un public d'étudiants, pour créer une fiche de lecture. 